\title{
PENGARUH PEMAKAIAN KOMBINASI MINYAK JINTEN HITAM (Nigella sativa) dan MADU (Apis mellifera) SEBAGAI ANTI-ACNE SECARA TOPIKAL PADA SUKARELAWAN WANITA
}

\section{THE EFFECT OF BLACK CUMIN (Nigella sativa) OIL AND HONEY (Apis mellifera) AS ANTI-ACNE TOPICALLY IN WOMEN VOLUNTEER}

\author{
Baiq Lenysia Puspita Anjani, Ari Sabar Hati, Halimah Az-Zahra, Fitri Rahmawanti, \\ dan Endang Darmawan \\ Fakultas Farmasi Universitas Ahmad Dahlan
}

Jln. Prof. Dr. Soepomo, Janturan, Yogyakarta, Telp. (0274) 379418

email:lenysia@rocketmail.com

Submitted : 08-06-2015 Reviewed : 15-09-2015 Accepted: 24-11-2015

\begin{abstract}
ABSTRAK
Jerawat paling sering diderita oleh remaja dengan prevalensi $85 \%$. Kebiasaan berganti-ganti kosmetik dapat mempengaruhi kejadian acne vulgaris. Penyembuhan jerawat dapat menggunakan bahan-bahan herbal seperti minyak jinten hitam dan madu. Minyak jinten hitam efektif untuk mengobati acne vulgaris ringan (mild) dan sedang (moderate). Madu memiliki khasiat dapat membunuh bakteri Propionibacterium acnes. Tujuan dari penelitian ini adalah untuk mengetahui aktivitas anti-acne pada pemakaian kombinasi minyak jinten hitam dan madu dengan perbandingan 1:1 selama 14 hari pada wanita. Penelitian ini termasuk penelitian eksperimental dengan pre-post treatment design study. Terdapat 2 kelompok, yaitu kelompok kontrol (6 sukarelawan wanita) dan kelompok perlakuan (6 sukarelawan wanita). Selama 14 hari, kelompok kontrol memakai obat kimia anti-acne, sedangkan kelompok perlakuan memakai kombinasi minyak jinten hitam dan madu dengan perbandingan 1:1. Analisis statistika yang digunakan yaitu independent sample t-test dengan taraf kepercayaan 95\%. Hasil penelitian menunjukkan bahwa kelompok perlakuan wanita yang memakai kombinasi minyak jinten hitam dan madu dengan perbandingan 1:1 selama 14 hari dibandingkan dengan kelompok kontrol wanita tidak terdapat perbedaan dalam menurunkan jumlah parameter komedo hitam, komedo putih, papul, pustul, hiperpigmentasi, eritema, pruritis, xerosis, desquamation, dan sunburn dengan nilai $p>0,05$. Kesimpulan penelitian ini adalah pemakaian kombinasi minyak jinten hitam dan madu dengan perbandingan 1:1 selama 14 hari berefek sebagai anti-acne pada wanita, namun secara statistik tidak bermakna.
\end{abstract}

Kata Kunci: anti-acne, minyak jinten hitam (Nigella sativa), madu (Apis mellifera).

\begin{abstract}
Acne mostly affects teenagers with prevalence of $85 \%$. Changing habits of cosmetics may affect the incidence of acne vulgaris. Healing acne can use herbal ingredients such as black cumin oil and honey. Black cumin oil effective for treating mild acne vulgaris and moderate acne vulgaris. Honey has property that can kill the bacteria Propionibacterium acnes. The purpose of this study is to determine the anti-acne activity in use of black cumin oil and honey combination in 1:1 ratio for 14 days in women. This study included experimental study with pre-post treatment study design. There are 2 groups, control group (six women volunteer) and treatment group (six women volunteer). For 14 days, control group use chemical drugs anti-acne, while treatment group use black cumin oil and honey combination in 1:1 ratio. Analysis of data used independent sample t-test with confidence interval 95\%. The results show that treatment group of women who use black cumin oil and honey combination in 1:1 ratio for 14 days compared with the control group of women there is no difference
\end{abstract}


in reducing the number of parameters black blackheads, white blackheads, papules, pustules, hyperpigmentation, erythema, pruritis, xerosis, desquamation, and sunburn with a value of $p>0.05$. The conclusion of this study is the use black cumin oil and honey combination in 1:1 ratio for 14 days has effect as anti-acne in women, but statistically not significant.

Keywords: anti-acne, black cumin oil (Nigella sativa), honey (Apis mellifera)

\section{PENDAHULUAN}

Jerawat paling sering diderita oleh remaja dengan prevalensi $85 \%$. Prevalensi terjadinya jerawat setelah remaja akan menurun dengan bertambahnya usia. Etnik yang berbeda mempengaruhi waktu timbulnya jerawat dan karakteristik jerawat. Orangtua yang memiliki riwayat jerawat mempengaruhi timbulnya jerawat pada anak-anak dimasa remajanya. Kebiasaan berganti-ganti kosmetik juga dapat mempengaruhi kejadian acne vulgaris (Dawson et al., 2012; Tjekyan, 2008).

Jerawat atau yang biasanya disebut dengan acne vulgaris adalah pembentukan komedo, papul, pustul, nodul dan/atau kista yang merupakan akibat dari sumbatan dan peradangan unit pilosebasea (folikel rambut dan kelenjar sebasea yang menyertainya). Acne dapat muncul di daerah yang banyak mengandung kelenjar pilosebasea, seperti pada daerah wajah, leher, dada, dan punggung. Bakteri yang menyebabkan terjadinya acne adalah Propionibacterium acnes (P. Acnes) (Truter, 2009; Dawson et $a l ., 2012)$. Jerawat pada wajah dapat mengganggu penampilan dan mengurangi rasa percaya diri. Saat ini, pengobatan jerawat diklinik biasanya menggunakan antibiotik baik secara oral maupun topikal. Antibiotik digunakan untuk menghambat inflamasi dan membunuh bakteri. Contoh antibiotik yang biasa digunakan, yaitu tetrasiklin, eritromisin, doksisiklin, dan klindamisin. Selain itu, sering juga digunakan benzoil peroksida, asam azelat dan retinoid. Namun, obat-obat tersebut memiliki efek samping dalam penggunaannya sebagai anti jerawat antara lain iritasi, sementara penggunaan antibiotika jangka panjang selain dapat menimbulkan resistensi juga dapat menimbulkan kerusakan organ dan imunohi persensitivitas (Djajadisastra et al., 2009).

Penyembuhan jerawat selain menggunakan bahan kimia seperti antibiotik, benzoil peroksida, asam azelat dan retinoid dapat menggunakan bahan-bahan herbal yang telah terbukti secara empiris maupun klinis. Bahan-bahan herbal yang dapat digunakan, antara lain minyak jinten hitam (Nigella sativa L.) dan madu (Apis mellifera L.) (Al-Harchan, 2010; Sabry, 2009).

Minyak jinten hitam mengandung thymoquinone yang memiliki khasiat sebagai antibakteri (Chaieb et al., 2011) dan anti-inflamasi (Kumar et al., 2010). Minyak jinten hitam juga banyak mengandung asam linoleat (44,7-56\%) yang diduga memiliki aktivitas dalam menghambat proliferasi sel epidermis folikuler yang dapat menghambat pertumbuhan acne (Movita, 2013). Minyak jinten hitam terbukti efektif untuk mengobati acne vulgaris ringan (mild) dan sedang (moderate) (AlHarchan, 2010).

Madu mengandung inhibin dan hidrogen peroksida yang memiliki khasiat sebagai antibakteri (Moussa et al., 2012). Selain itu, madu juga memiliki khasiat sebagai anti-inflamasi, anti-oksidan, dan dapat membunuh bakteri P. acnes penyebab acne (Vallianoul et al., 2014; Sabry, 2009). Khasiat yang dimiliki oleh minyak jinten hitam dan madu dapat dikombinasi sebagai obat anti-acne. Berdasarkan penelitian yang telah ada, kombinasi minyak jinten hitam dan madu tidak menimbulkan interaksi atau reaksi yang tidak diinginkan (Abdelmalek et al., 2012). Oleh karena khasiat yang dimiliki oleh jinten hitam dan madu yang dapat digunakan sebagai anti-acne, maka dilakukan penelitian secara klinis tentang pengaruh kombinasi minyak jinten hitam dan madu sebagai anti-acne.

Rumusan masalah penelitian ini adalah apakah pemakaian kombinasi minyak jinten hitam dan madu dengan perbandingan 1:1 selama 14 hari dapat berefek sebagai anti-acne pada wanita. Tujuan penelitian ini adalah untuk mengetahui aktivitas anti-acne pada pemakaian kombinasi minyak jinten hitam dan madu dengan perbandingan 1:1 selama 14 hari pada wanita. Manfaat penelitian ini adalah mendapatkan obat herbal anti-acne dari kombinasi madu dan minyak jinten hitam dan dapat sebagai literatur untuk membuktikan khasiat suatu bahan obat. 


\section{METODE PENELITIAN}

\section{Alat dan Bahan}

Alat-alat yang digunakan diantaranya adalah alat pres biji jinten hitam, botol plastik, dan gelas ukur. Bahan-bahan yang digunakan adalah madu dan biji jinten hitam.

\section{Jalannya Penelitian}

Penelitian ini termasuk penelitian eksperimental dengan rancangan penelitian pre-post treatment design study. Pada penelitian ini menggunakan 12 sukarelawan wanita yang dibagi dalam dua kelompok, yaitu kelompok kontrol dan kelompok perlakuan. Sukarelawan pada penelitian ini telah memenuhi kriteria inklusi, eksklusi, dan menandatangani informed consent.

Kriteria inklusi, yaitu memiliki acne ringan (mild acne) dan acne sedang (moderate acne) pada wajah, usia lebih dari 16 tahun, bersedia menerima instruksi dari peneliti sampai penelitian selesai, bersedia untuk tidak mengubah kebiasaan hidup normal, mengenai: makanan, aktivitas fisik, dan pembersih wajah, bersedia untuk tidak menerima obat atau pengobatan kosmetik lainnya yang dapat mengganggu hasil penelitian, dan bersedia untuk menandatangani formulir informed consent. Kriteria eksklusi yaitu, kulit wajah sensitive, merokok, mengkonsumsi alkohol, hamil, dan menyusui.

Dua belas sukarelawan wanita sebelum dilakukan penelitian dibawa ke dokter kulit untuk pemeriksaan awal. Setelah penelitian selesai, dua belas sukarelawan wanita dibawa ke dokter untuk mengetahui ada tidaknya perubahan setelah dilakukan penelitian seperti pada Gambar 1.

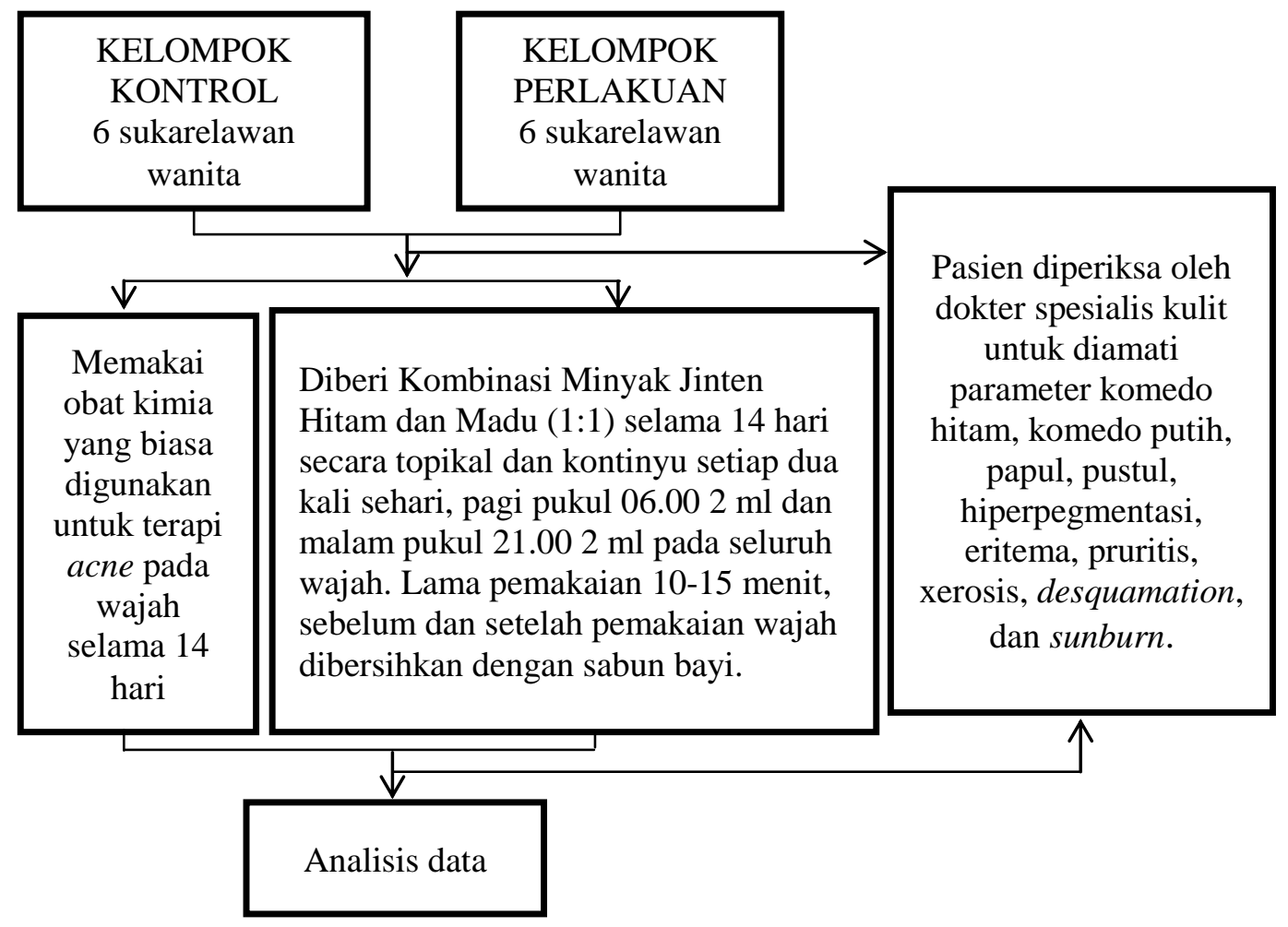

\section{Gambar 1. Skema pelaksanaan penelitian}

\section{Cara Pemilihan Sampel}

Sampel dipilih secara consecutive sampling sebanyak 12 sukarelawan wanita yang memiliki jerawat di wajah dan memenuhi kriteria inklusi dan eksklusi yang telah ditetapkan dalam kurun waktu tertentu hingga jumlah subjek penelitian terpenuhi.

\section{Tipe Penyamaran (Blinding)}

Tipe penyamaran yang digunakan, yaitu terbuka atau tanpa penyamaran. Subjek studi mengetahui perlakuan yang diberikan dan peneliti mengetahui alokasi perlakuan yang diberikan pada kelompok perlakuan dan kelompok kontrol. 
Analisis Statistika

Analisis statistika yang digunakan untuk melihat adanya efek kombinasi minyak jinten hitam dan madu sebagai anti-acne, yaitu dengan analisis independent samples $t$ test atau uji t tidak berpasangan. Taraf kepercayaan yang digunakan, yaitu $95 \%$.

\section{HASIL DAN PEMBAHASAN}

Minyak jinten hitam yang digunakan dalam penelitian ini dilakukan uji KLT untuk mengetahui kadar thymoquinone. Hasil dari uji KLT minyak jinten hitam yang digunakan pada penelitian ini menunjukkan adanya thymoquinone sebesar $2,22 \% \mathrm{~b} / \mathrm{b}$. Minyak jinten hitam dan madu yang digunakan pada penelitian ini dianalisis menggunakan GCMS untuk mengetahui kandungannya. Dari hasil analisis minyak jinten hitam dan madu menggunakan GCMS diketahui bahwa kandungannya yang paling banyak atau kandungan utamanya adalah asam linoleat. Kadar asam linoleat pada minyak jinten hitam sebesar $34,12 \%$ dan kadar asam linoleat pada madu sebesar $33,25 \%$. Data hasil pemeriksaan pada hari ke-0 dan hari ke-14 yang telah diperoleh dianalisis dengan uji statistik independent samples t test menggunakan SPSS 16.0. Hasil uji statistik dapat dilihat pada Tabel I, sedangkan Grafik data hasil pemeriksaan hari ke-0 dan hari ke-14 yang diperoleh dapat dilihat pada Gambar 2 dan Gambar 3.

Tabel I. Hasil uji statistik pada hasil pemeriksaan hari ke-0 dan hari ke-14 kelompok kontrol dan kelompok perlakuan pada sukarelawan wanita

\begin{tabular}{cc}
\hline Parameter & $P$ \\
\hline Komedo Hitam & 0,081 \\
Komedo Putih & 0,657 \\
Papul & 0,443 \\
Pustul & 0,713 \\
Hiperpegmentasi & 0,231 \\
Eritema & 0,005 \\
Xerosis & 0,065 \\
Desquamation & 0,049 \\
Sunburn & 0,138 \\
\hline
\end{tabular}

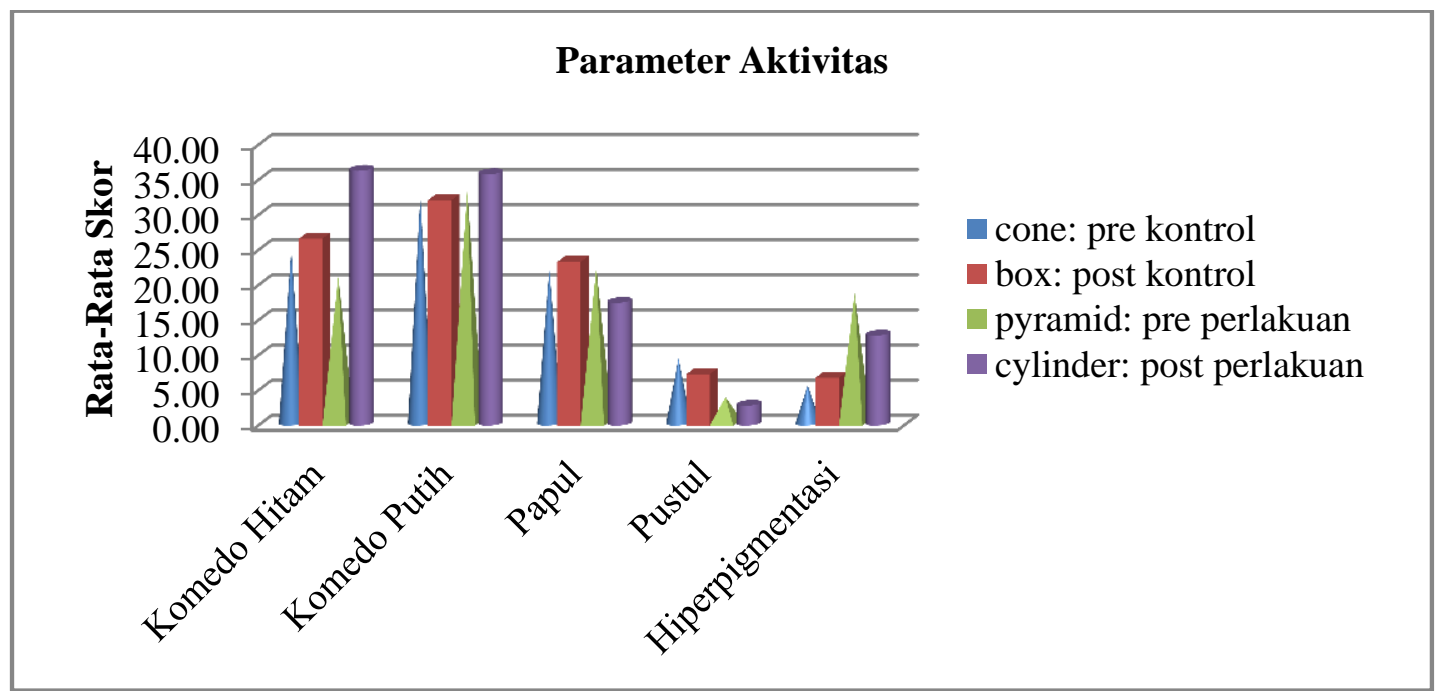

Gambar 2. Grafik perbandingan parameter aktivitas kelompok kontrol dengan kelompok perlakuan pada sukarelawan wanita

Hasil uji statistik menunjukkan bahwa nilai $p>0,05$ pada seluruh parameter (komedo hitam, komedo putih, papul,pustul, hiperpigmentasi, xerosis, sunburn) kecuali eritema dan desquamation, artinya tidak terdapat perbedaan antara kelompok kontrol dengan kelompok perlakuan dalam 
penurunan skor setiap parameter pada wanita, kecuali eritema dan desquamation dengan nilai $p<0,05$, tetapi karena parameter eritema dan desquamation bukan merupakan parameter aktivitas tetapi hanya parameter keamanan, maka dapat disimpulkan bahwa kombinasi minyak jinten hitam dan madu dengan perbandingan 1:1 selama 14 hari tidak berefek sebagai anti-acne pada wanita.

Grafik pada Gambar 2 menunjukkan bahwa persen selisih dari rata-rata skor hasil pemeriksaan hari ke-0 dan hari ke-14 terdapat kenaikan dan penurunan jumlah parameter pada kelompok perlakuan dan kelompok kontrol wanita. Pada kelompok kontrol wanita terdapat kenaikan jumlah komedo hitam sebesar $8,11 \%$; penurunan jumlah komedo putih sebesar $0,52 \%$; kenaikan jumlah papul sebesar 6,87\%; penurunan jumlah pustul sebesar $20 \%$; kenaikan jumlah hiperpigmentasi sebesar 28,13\%. Pada kelompok perlakuan wanita, persen selisih dari rata-rata skor hasil pemeriksaan setiap parameter pada hari ke-0 dan hari ke-14 terdapat kenaikan jumlah komedo hitam sebesar 74,41\%; kenaikan jumlah komedo putih sebesar 8,02\%; penurunan jumlah papul sebesar 21,06\%; penurunan jumlah pustul sebesar 22,89\%; penurunan jumlah hiperpegmentasi sebesar 30,65\%.

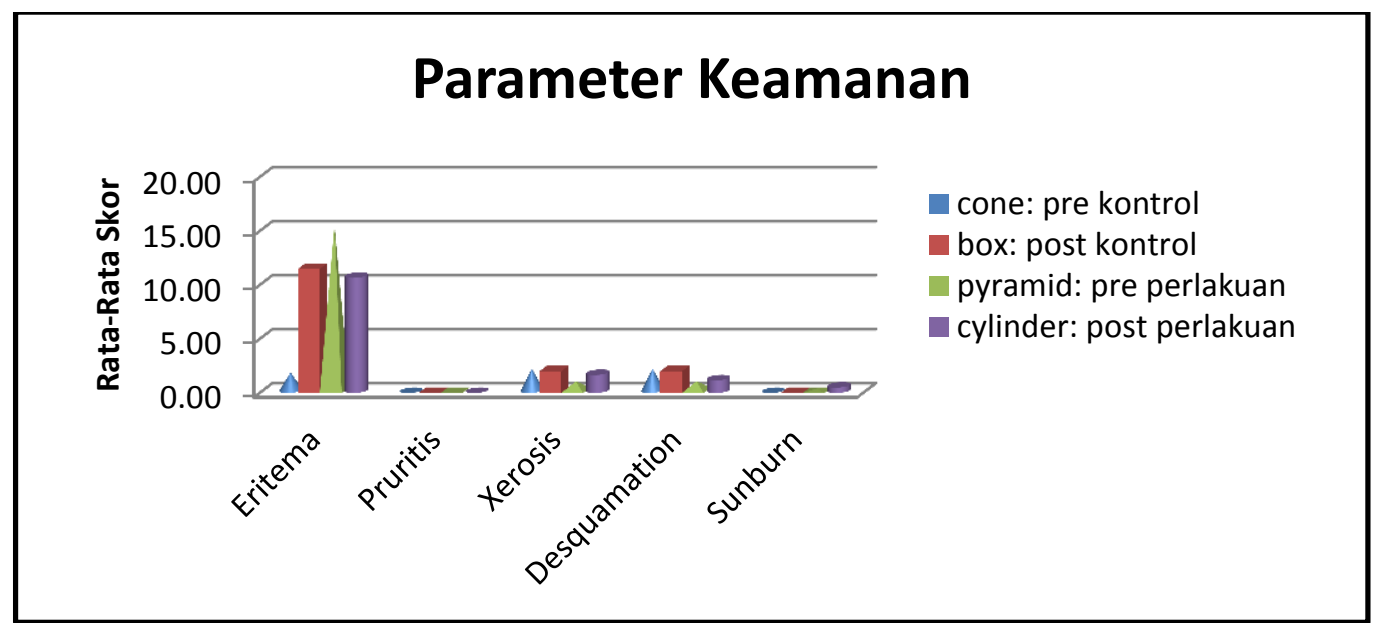

Gambar 3. Grafik perbandingan parameter keamanan kelompok kontrol dengan kelompok perlakuan pada sukarelawan wanita

Grafik pada Gambar 3 menunjukkan bahwa persen selisih dari rata-rata skor hasil pemeriksaan hari ke-0 dan hari ke-14 terdapat kenaikan dan penurunan jumlah parameter pada kelompok perlakuan dan kelompok kontrol wanita. Pada kelompok kontrol wanita terdapat kenaikan jumlah eritema sebesar 590\%; untuk parameter pruritis, xerosis, desquamation, dan sunburn tidak ada kenaikan ataupun penurunan (tetap). Pada kelompok perlakuan, persen selisih dari rata-rata skor hasil pemeriksaan setiap parameter pada hari ke-0 dan hari ke-14 terdapat penurunan jumlah eritema sebesar 30,40\%; kenaikan xerosis sebesar 101,20\%; kenaikan jumlah desquamation sebesar 40,96\%; kenaikan jumlah sunburn sebesar 194,12\%; untuk parameter pruritis tidak ada kenaikan ataupun penurunan (tetap).

Penurunan jumlah parameter yang terjadi pada kelompok kontrol adalah parameter komedo putih dan pustul. Sedangkan untuk kelompok perlakuan terjadi penurunan jumlah parameter pada papul, pustul, hiperpegmentasi, dan eritema. Pemakaian kombinasi minyak jinten hitam dan madu dengan perbandingan 1:1 selama 14 hari hanya dapat menurunkan jumlah papul, pustul, hiperpegmentasi, dan eritema pada wanita. Sehingga, dapat disimpulkan bahwa kombinasi minyak jinten hitam dan madu dengan perbandingan 1:1 selama 14 hari berefek sebagai anti-acne pada wanita, namun secara statistik tidak menunjukkan adanya perbedaan yang bermakna.

Adanya perbedaan pengambilan kesimpulan secara statistik dan grafik dapat disebabkan oleh beberapa faktor yang mempengaruhi penelitian ini. Beberapa faktor yang dapat mempengaruhi penelitian ini, diantaranya premenstruasi, pola hidup, dan makanan.

Jadwal menstruasi pada wanita setiap bulannya dapat menimbulkan kejadian acne. Aktivitas kelenjar sebasea yang meningkat dipengaruhi oleh hormon androgen, tetapi pada wanita hormon androgen tidak meningkat pada sekitar periode menstruasi. Penjelasan untuk peningkatan aktivitas kelenjar sebasea sekitar periode menstruasi mungkin tidak berhubungan dengan kadar hormon 
androgen pada wanita tetapi lebih berhubungan dengan kadar hormon estrogen yang sangat rendah tepat sebelum dan selama periode menstruasi. Hal ini menyebabkan pada periode menstruasi perempuan lebih banyak menderita acne vulgaris maupun eksaserbasinya (Sarrel, 2011).

Pola hidup yang tidak baik seperti tidur terlalu larut malam dapat memperparah acne. Tidur yang terlalu larut memiliki peran dalam peningkatan level stress, sehingga sekresi kortisol lebih sedikit. Hal ini dapat menyebabkan tubuh tidak siap untuk menghadapi stress dan mengakibatkan kulit memproduksi sebum lebih banyak (Pujiastuti, 2012).

Makanan berlemak, mentega, telur, kacang-kacangan, gorengan, makanan pedas, manisan seperti coklat, biskuit, dan kue merupakan faktor yang dapat memperparah acne. Makanan tersebut dapat mempengaruhi metabolisme tubuh sehingga mengaktifkan kelenjar pilosebasea untuk menghasilkan sebum dan bila terjadi penyumbatan pada folikelnya maka dapat menjadi awal dari acne, namun metabolisme tubuh setiap individu berbeda-beda sehingga reaksi yang terjadi pada kelenjar pilosebasea tidak sama pada setiap individu (El-Akawi et al., 2006; Tjekyan, 2008).

\section{KESIMPULAN}

Pemakaian kombinasi minyak jinten hitam dan madu dengan perbandingan 1:1 selama 14 hari berefek sebagai anti-acne pada wanita, namun secara statistik tidak bermakna.

\section{UCAPAN TERIMAKASIH}

Penulis mengucapkan terimakasih kepada dr. Nafiah Chusniyati, M.Sc., Sp.KK dan seluruh karyawan RS PKU Muhammadiyah atas bantuannya selama penelitian, serta keluarga dan temanteman yang telah mendukung penulis secara moril maupun materiil.

\section{DAFTAR PUSTAKA}

Abdelmalek, M., Moussa, A., Noureddine, D., and Saad, A., 2012, Antibacterial Activity of Honey Alone and in Combination with Nigella sativa Seeds Against Pseudomonas aeruginosa Infection, Asian Pacific Journal of Tropical Disease, S428-S430.

Abu-Zinadah, O.A., 2009, Using Nigella sativa Oil to Treat and Heal Chemical Induced Wound of Rabit Skin, JKAU, 21(2): 335-346.

Ahmad, A., Husain, A., Mujeeb, M., Khan, S.A., Najmi, A.K., Siddique, N.A., Damanhouri, Z.A., and Anwar, F., 2013, A Review on Therapeutic Potential of Nigella sativa: A Miracle Herb, Asian Pacific Journal of Tropical Biomedicine, 3(5): 337-352.

Al-Harchan, N.A.H., 2010, Treatment of Acne vulgaris with Nigella sativa Oil Lotion, The Iraqi Postgraduate Medical Journal, 9(2): 140-144.

Ayer, J. and Burrows, N., 2006, Acne: More than Skin Deep, Postgraduate Medical Journal, 82: 500506.

Chaieb, K., Kouidhi, B., Jrah, H., Mahdouani, K., and Bakhrouf, A., 2011, Antibacterial Activity of Thymoquinone an Active Principle of Nigella sativa and its Potency to Prevent Bacterial Biofilm Formation, BMC Complementary and Alternative Medicine, 11(29): 1-6.

Dawson, A.L., Knutsen-Larson, S., Dunnick, C.A., and Dellavalle, R.P., 2012, Acne vulgaris: Pathogenesis, Treatment, and Needs Assesment, Dermatol Clin, 30: 99-106.

Djajadisastra, J., Mun'im, A., dan P, Dessy N., 2009, Formlasi Gel Topikal dari Ekstrak Nerii Folium dalam Sediaan Anti Jerawat, Jurnal Farmasi Indonesia, 4(4): 210-216.

El-Akawi, Z., Nemr, N.A., Abdul-Razzak, K., and Al-Aboosi, M., 2006, Factor Believed by Jordanin Acne Patients to Affect their Acne Condition, La Revue de Santé de la Méditerranée orientale, 12(6): 840-846.

Kumar, T.V.S., Negi P.S., and Sankar K.U., 2010, Antibacterial Activity of Nigella sativa L. Seed Extracts, British Journal of Pharmacology and Toxicology, 1(2): 96-100.

Movita, T., 2013, Acne Vulgaris, Continuing Medical Education, 40(4): 269-272.

Pujiastuti, D.S., 2012, Hubungan antara Waktu Tidur Malam dengan Terjadinya Akne Vulgaris Di RSU Dr.Soedarso Pontianak, Naskah Publikasi, Program Studi Pendidikan Dokter Fakultas Kedokteran Universitas Tanjungpura, Kalimantan Barat.

Sabry, E.Y., 2009, A Three-Stage Strategy in Treating Acne Vulgaris in Patients with Atopic Dermatitis- A Pilot Study, Journal of Pakistan Association of Dermatologists, 19: 95-105. 
Sarrel, P.M., 2011, Androgen, http://www.healthywomen.org/condition/androgen, diakses tanggal 29 April 2015.

Tjekyan, R.M.S., 2008, Kejadian dan Faktor Resiko Akne Vulgaris, Media Medika Indonesia, 43(1): 37-43.

Truter, I., 2009, Evidence-based Pharmacy Practice (EBPP): Acne vulgaris, SA Pharmaceutical Journal.

Vallianoul, N.G., Gounaril, P., Skourtis, A., Penagos, J., and Kazazis, C., 2014, Honey and its AntiInflammatory, Anti-Bacterial and Anti-Oxidant Properties, General Medicine: Open access ISSN: 2327-5146 GMO, 2(2): 1-5.

Wasitaatmadja, S.M., 2001. Masalah Jerawat pada Remaja. Dalam: Tjokronegoro, A., Utama, H., ed. Pengobatan Mutakhir Dermatologi pada Anak dan Remaja. Jakarta: FK-UI, 70-77.

Webster, G.F. and Graber, E.M., 2008, Antibiotic Treatment for Acne vulgaris, Semin Cutan Med Surg, 27: 183-187.

Wu, Q., 2011, Antimicrobial Effect of Manuka Honey and Kanuka Honey Alone and in Combination with the Bioactives Against the Growth of Propionibacterium acnes ATCC 6919, Thesis, Master of Food Technology Massey University Albany, New Zealand. 
